\title{
Characterization and engineering of a DNA polymerase reveals a single amino-acid substitution in the fingers subdomain to increase strand-displacement activity of A-family prokaryotic DNA polymerases
}

Yvonne Piotrowski, Man Kumari Gurung and Atle Noralf Larsen *i)

\begin{abstract}
Background: The discovery of thermostable DNA polymerases such as Taq DNA polymerase revolutionized amplification of DNA by polymerase chain reaction methods that rely on thermal cycling for strand separation. These methods are widely used in the laboratory for medical research, clinical diagnostics, criminal forensics and general molecular biology research. Today there is a growing demand for on-site molecular diagnostics; so-called 'Point-of-Care tests'. Isothermal nucleic acid amplification techniques do not require a thermal cycler making these techniques more suitable for performing Point-of-Care tests at ambient temperatures compared to traditional polymerase chain reaction methods. Strand-displacement activity is essential for such isothermal nucleic acid amplification; however, the selection of DNA polymerases with inherent strand-displacement activity that are capable of performing DNA synthesis at ambient temperatures is currently limited.
\end{abstract}

Results: We have characterized the large fragment of a DNA polymerase I originating from the marine psychrophilic bacterium Psychrobacillus sp. The enzyme showed optimal polymerase activity at $\mathrm{pH} 8-9$ and $25-110 \mathrm{mM} \mathrm{NaCl} / \mathrm{KCl}$. The polymerase was capable of performing polymerase as well as robust strand-displacement DNA synthesis at ambient temperatures $\left(25-37^{\circ} \mathrm{C}\right)$. Through molecular evolution and screening of thousand variants we have identified a single amino-acid exchange of Asp to Ala at position 422 which induced a 2.5-fold increase in strand-displacement activity of the enzyme.

Transferring the mutation of the conserved Asp residue to corresponding thermophilic homologues from Ureibacillus thermosphaericus and Geobacillus stearothermophilus also resulted in a significant increase in the strand-displacement activity of the enzymes.

Conclusions: Substituting Asp with Ala at positon 422 resulted in a significant increase in strand-displacement activity of three prokaryotic A-family DNA polymerases adapted to different environmental temperatures i.e. being psychrophilic and thermophilic of origin. This strongly indicates an important role for the 422 position and the O1-helix for strand-displacement activity of DNA polymerase I. The D422A variants generated here may be highly useful for isothermal nucleic acid amplification at a wide temperature scale.

Keywords: DNA polymerase, Enzyme engineering, Strand displacement, Molecular evolution, Isothermal amplification, Point-of-care

\footnotetext{
* Correspondence: atle.larsen@uit.no

Department of Chemistry, Faculty of Science and Technology, SIVA

Innovation Centre, Sykehusvegen 23, UiT - The Arctic University of Norway,

9037 Tromsø, Norway
}

(c) The Author(s). 2019 Open Access This article is distributed under the terms of the Creative Commons Attribution 4.0 International License (http://creativecommons.org/licenses/by/4.0/), which permits unrestricted use, distribution, and reproduction in any medium, provided you give appropriate credit to the original author(s) and the source, provide a link to the Creative Commons license, and indicate if changes were made. The Creative Commons Public Domain Dedication waiver (http://creativecommons.org/publicdomain/zero/1.0/) applies to the data made available in this article, unless otherwise stated. 


\section{Background}

DNA polymerases have been classified into seven families (A, B, C, D, X, Y, RT) based on their amino-acid sequence and structural homology [1]. These different families have distinct structural and functional properties needed to fulfill their different biological roles in nucleic-acid metabolism. The A-family DNA polymerases include both, replicative and repair polymerases. Prokaryotic A-family DNA polymerases, referred to as polymerase I, have two functional domains encoded within the same polypeptide chain, a $5^{\prime}-3^{\prime}$ polymerase domain and a $5{ }^{\prime}-3$ ' exonuclease domain unique among all DNA polymerases (reviewed in [2]). In addition, some polymerase I enzymes also contain a proofreading $3^{\prime}-5^{\prime}$ exonuclease domain, the main function of which is to remove errors during DNA replication, e.g. Escherichia coli DNA polymerase I (E. coli, reviewed in [2]).

Various A-family DNA polymerases are extensively used for in vitro amplification of DNA in molecular biology and diagnostic applications [3, 4], exemplified by the Taq DNA polymerase which is famous as the enzyme originally used in polymerase chain reaction (PCR, [5]). Other well-characterized enzymes from this family include the large fragment (LF) of E. coli DNA polymerase I, also known as the Klenow fragment [6], and the LF of Geobacillus stearothermophilus polymerase I (Gbst pol I LF, [7]). Gbst pol I LF is also able to perform strand displacement (SD) where the complement strand downstream of the polymerization direction is displaced simultaneously with nucleotide addition.

The structure of a DNA polymerase I, can be described in terms of a human right hand, with three subdomains referred to as the thumb, fingers, and palm (reviewed in [2]). Kaushik et al. [8] showed in their study that residues in the $\mathrm{O}$ - and $\mathrm{O} 1$-helix of the fingers subdomain are important for the polymerase function. A later study by Singh et al. [9] indicated that residues particular present in the O1-helix are essential for stranddisplacement synthesis. The property of strand displacement allows Gbst pol I LF to be used in various isothermal nucleic acid amplification techniques (INAATs) such as loop-mediated isothermal amplification (LAMP, [10]) as strand separation is induced by the enzyme itself, rather than heat denaturation as used in PCR.

Globally, there is a high demand to monitor and diagnose critical infectious diseases. Continuous development of on-site molecular diagnostic tests, recently referred to as Point-of-Care (POC) tests, are needed to rapidly identify a specific pathogen and provide information on susceptibility to antimicrobial agents directing appropriate treatment [11]. The characteristics of an ideal new POC diagnostic test, valid also for low-resource settings, should meet the ASSU RED criteria. The acronym ASSURED was originally coined at a 2003 WHO Special Programme for Research and Training in Tropical Diseases (WHO/ TDR, [12]).

PCR meets necessary diagnostic requirements in terms of specificity, sensitivity and rapidity, but involves several steps and requires trained skilled technical personnel to perform sample preparation, DNA amplification and detection. In addition, PCR needs an accurate thermal cycler to perform the PCR reactions. In a POC setting, INAAT represents an enabling technology with the potential to offer rapid, sensitive and specific molecular diagnosis of infectious diseases aiming at meeting the ASSURED criteria (reviewed in [13]). In many of these methods, efficient target amplification relies on the inherent SD activity of the DNA polymerase used in the amplification step $[14,15]$. Most of the currently used A-family DNA polymerases on the market, e.g. from $\mathrm{Ba}$ cillus stearothermophilus and Bacillus smithii, have optimal performance at $60-65^{\circ} \mathrm{C}$ and are less efficient in isothermal nucleic acid amplification at ambient temperatures required in POC settings.

In the present study we have recombinantly produced and characterized the large fragment of Psychrobacillus sp. DNA polymerase I (PB pol I LF), demonstrating that this enzyme exhibits efficient polymerase and SD activity at ambient temperatures. We have further improved this native SD activity through molecular evolution by introducing a single-point mutation in the fingers subdomain resulting in an increase of $150 \%$ (2.5 fold). Altering the equivalent residue in two thermostable A-family DNA polymerases resulted in a significant increase also in their SD activity (2.1 to 2.4 fold). We believe this study will contribute to the understanding of strand-displacement DNA synthesis by A-family DNA polymerases, potentially spurring development of new POC tests based on polymerasedriven isothermal amplification techniques.

\section{Results and discussion}

The effect of $\mathrm{pH}$, salt $(\mathrm{NaCl}, \mathrm{KCl})$ and $\mathrm{Mg}^{2+}$ on the polymerase activity were determined for PB pol I LF using a time-resolved polymerase activity assay with a molecular beacon substrate (see Methods). PB pol I LF showed highest polymerase activity at $\mathrm{pH} 8.5$ and in the presence of 40 $110 \mathrm{mM} \mathrm{NaCl}$ or $25-80 \mathrm{mM} \mathrm{KCl}$ (Fig. 1a and b). PB pol I LF had an absolute requirement for $\mathrm{Mg}^{2+}$ to perform DNA synthesis, hence no polymerase activity could be detected in the absence of $\mathrm{Mg}^{2+}$, and showed a decrease in polymerase activity at $\mathrm{Mg}^{2+}$ concentrations $>8 \mathrm{mM}$ (Fig. $1 \mathrm{c}$ inset). PB pol I LF exhibited optimal performance at $\left[\mathrm{Mg}^{2+}\right]$ in the range of $2-8 \mathrm{mM}$ (Fig. 1c). The temperature optimum for polymerase activity and effect of temperature on the stability of PB pol I LF were determined using the single-nucleotide incorporation endpoint assay (see Methods). PB pol I LF showed moderate activity between $25^{\circ}$ and $40^{\circ} \mathrm{C}$, with 

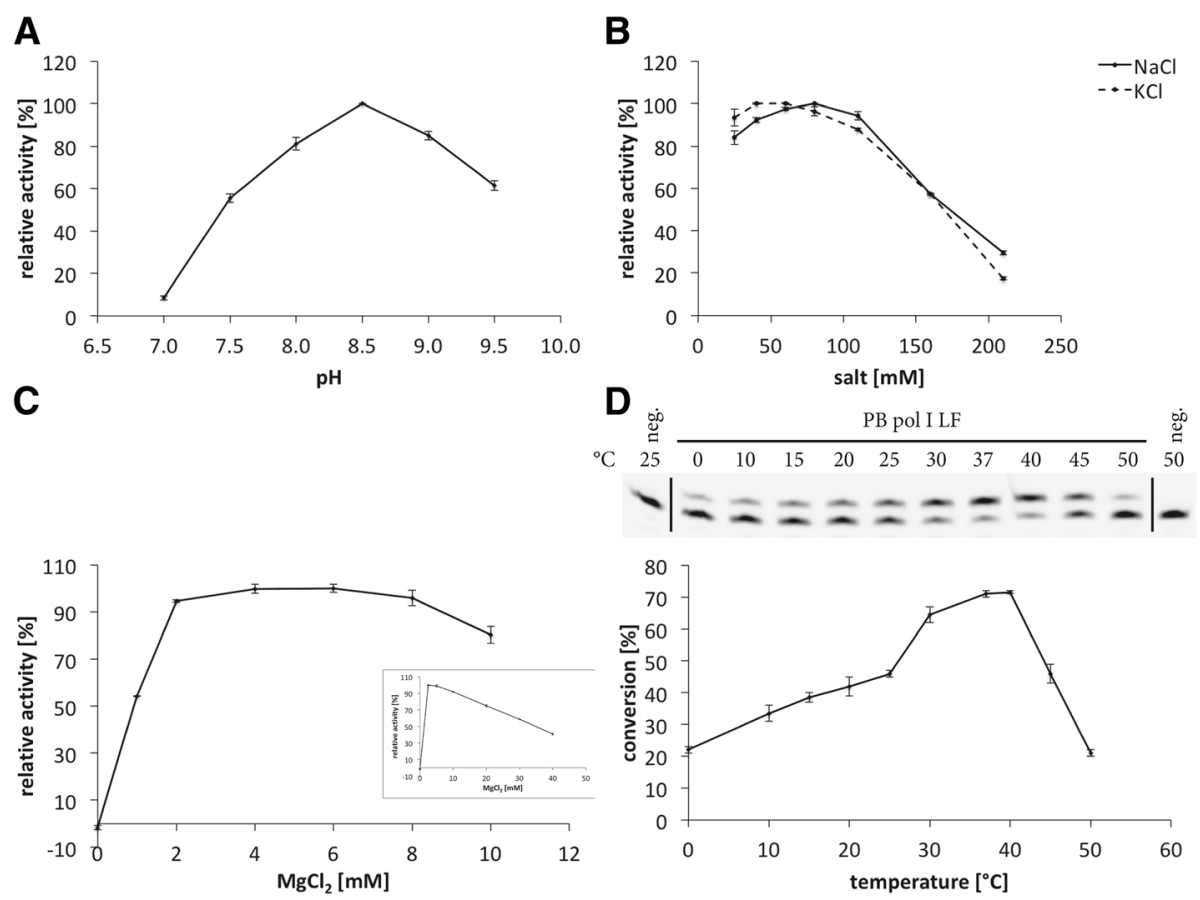

Fig. 1 A-D Basic characterization of polymerase I large fragment from Psychrobacillus sp. The effect of pH (a), salt (b) and $\mathrm{Mg}^{2+}(\mathbf{c}$, inset showing polymerase activity at 0-40 $\mathrm{mM} \mathrm{MgCl}_{2}$ ) have been measured with the time-resolved molecular beacon assay at $25^{\circ} \mathrm{C}$. The increase in Fluorescein fluorescence, i.e. enzyme activity, has been measured as relative fluorescence units (RFUs). For the reactions 37.5 ng protein were used. Effect of temperature (d) on the polymerase activity was tested with the single-nucleotide incorporation endpoint assay and densitometric analysis of the bands after denaturing polyacrylamide gel electrophoresis (12\% polyacrylamide/7 M urea). For the reactions $180 \mathrm{pg}$ protein were used. The gel is shown on top (neg. = negative control) and the evaluation of the densitometry at the bottom

an optimum at $37^{\circ} \mathrm{C}$ (Fig. 1d). PB pol I LF was rapidly inactivated when incubated at temperatures above $40{ }^{\circ} \mathrm{C}$ (Fig. 2).

One of the most important properties for a polymerase-driven isothermal nucleic acid amplification method is the ability of the polymerase to perform strand displacement of dsDNA. Using the SD activity assay as described in Methods, PB pol I LF was demonstrated to perform strand-displacement DNA synthesis at $25^{\circ} \mathrm{C}$, $30^{\circ} \mathrm{C}$ and $37^{\circ} \mathrm{C}$ (Fig. 3). In order to gain information about residues involved in SD DNA synthesis and to develop a more potent enzyme for use in isothermal amplification methods we sought to increase the SD activity of the enzyme by molecular evolution. A thousand variants from the generated evolution library (see Methods) were expressed recombinantly, semi-purified and screened for SD activity using the time-resolved stranddisplacement activity assay. Fourteen variants showed a significant increase in SD activity (> 1.5 fold) compared to the wild type enzyme of PB pol I LF. These variants were produced in larger scale $(500 \mathrm{ml})$ and purified to homogeneity (>95\% purity determined by SDS-PAGE, Additional file 1). Out of the fourteen variants three still showed a significant increase in SD activity. The focus of this article is on the variant that showed the highest increase in SD activity of $150 \%$ (2.5 fold) at $25^{\circ} \mathrm{C}$ (Fig. 4a). Sequencing analysis revealed a single base exchange at position 1265 from adenine to cytosine. The exchange of this base in the second position of the triplet originally encoding for an aspartate residue (GAT) led to a substitution to an alanine residue (GCT) at position 422 in the protein sequence of PB pol I LF (Additional file 2). The effect of the D422A substitution on polymerase activity was less pronounced and showed only an increase of about 1.4 fold (Fig. 4b), indicating that the D422A substitution mostly affected the SD function of the enzyme. Several other amino-acid substitutions have been tested in position 422, i.e. Ser, Lys, Val, Leu, Asn. These mutations cover the effect of substituting the Asp residue to other (larger) hydrophobic residues and polar residues of different length as well as a positive charged residue. All mutations resulted in improvement in the strand-displacement activity (Additional file 3), indicating that substituting the negatively charged Asp residue is beneficial for the strand-displacement capacity of the enzyme. The D422A mutation provides the substitution with the best enzyme performance.

To investigate whether the increase in SD activity induced by the D422A substitution was specific for PB pol 

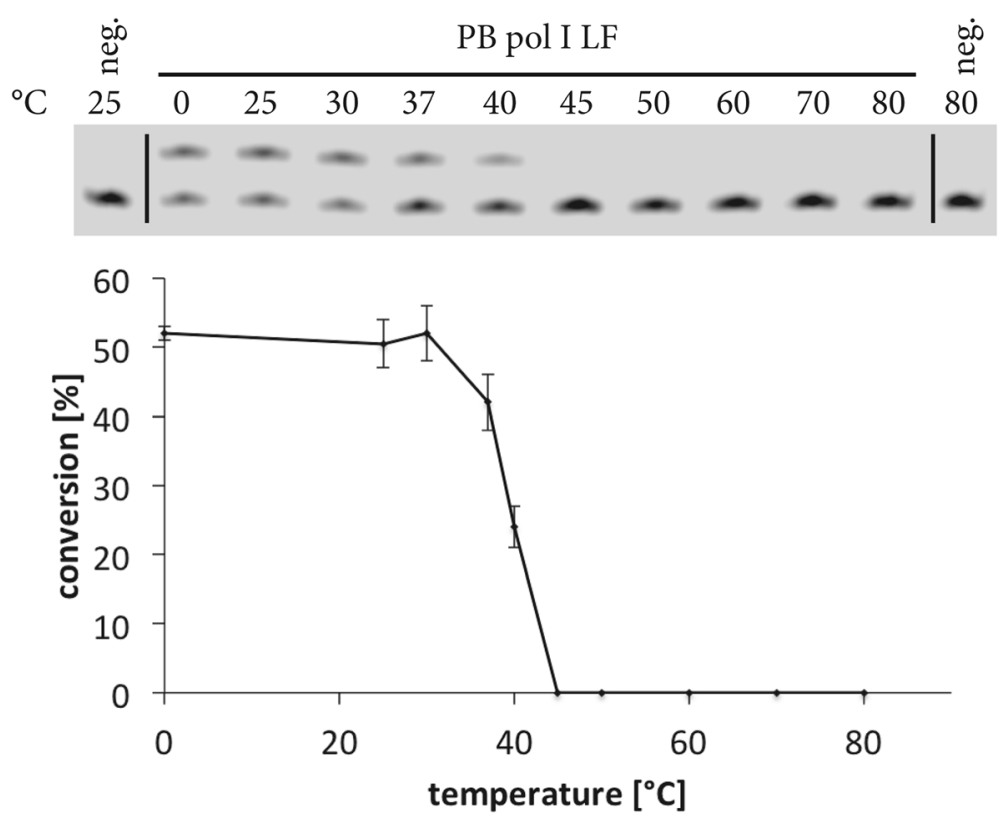

Fig. 2 Temperature stability of polymerase I large fragment from Psychrobacillus sp. The thermal stability has been measured using the singlenucleotide incorporation endpoint assay and densitometric analysis (line chart at the bottom) of the bands after denaturing polyacrylamide gel electrophoresis (12\% polyacrylamide/7 M urea, gel on top, neg. = negative control). After incubation of the reaction set-ups at the respective temperature the enzymatic reaction has been performed in $50 \mathrm{mM}$ BIS-Tris propane $\mathrm{pH} 8.5$ (at $25^{\circ} \mathrm{C}$ ), $100 \mathrm{mM} \mathrm{NaCl}, 5 \mathrm{mM} \mathrm{MgCl} 2,1 \mathrm{mM} \mathrm{DTT}, 0.2$ $\mathrm{mg} / \mathrm{ml} \mathrm{BSA}$ and $2 \%$ glycerol. For the reactions $180 \mathrm{pg}$ protein were used

I LF only, or whether 422 is an important position for SD DNA synthesis in other A-family DNA polymerases, a search for homologous proteins using Protein BLAST [16] was performed. The large fragment of DNA polymerase I from Ureibacillus thermosphaericus (Ubts pol I LF) and Geobacillus stearothermophilus (Gbst pol I LF) were chosen as thermophilic representatives. Ubts pol I
LF and Gbst pol I LF have sequence identities of 60 and $67 \%$ with PB pol I LF, respectively.

Examination of the three-dimensional structure of Gbst pol I LF (PDB code: 1XWL) revealed that the amino-acid residue corresponding to the 422 position resides on a short $\alpha$-helix, i.e. O1-helix. This $\alpha$-helix is comprised of 44 amino-acid residues and is part of the

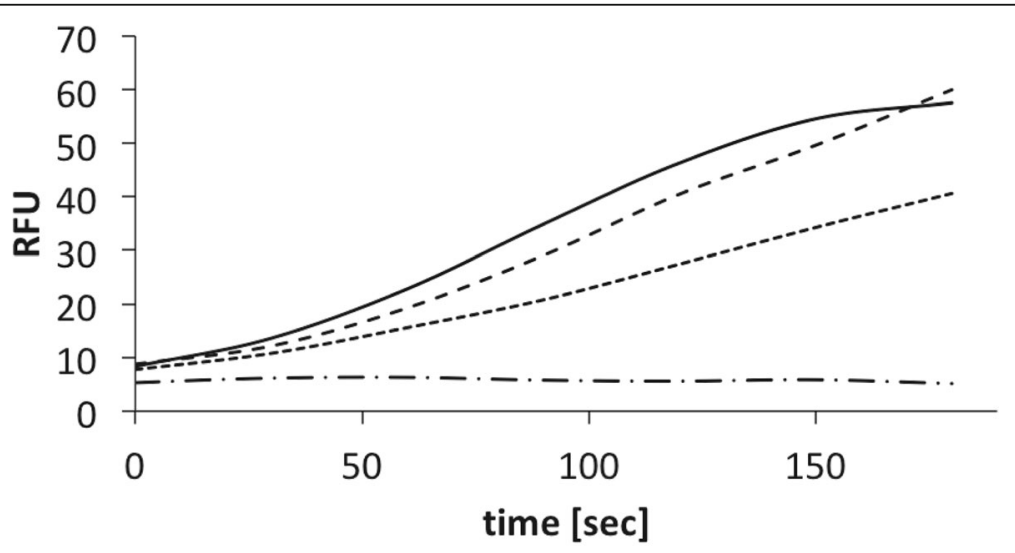

----25 ${ }^{\circ} \mathrm{C}---30{ }^{\circ} \mathrm{C}-37{ }^{\circ} \mathrm{C}-\cdot-$ negative

Fig. 3 Strand-displacement activity of polymerase I large fragment from Psychrobacillus sp. at various temperatures. The strand-displacement activity assays have been performed in $50 \mathrm{mM}$ BIS-Tris propane $\mathrm{pH} 8.5,100 \mathrm{mM} \mathrm{NaCl}, 5 \mathrm{mM} \mathrm{MgCl} 2,1 \mathrm{mM} \mathrm{DTT}, 0.2 \mathrm{mg} / \mathrm{ml} \mathrm{BSA}$ and $2 \% \mathrm{glycerol}$. The increase in TAMRA fluorescence, i.e. enzyme activity, has been measured as relative fluorescence units (RFUs). For the reactions $100 \mathrm{ng}$ protein were used. "Negative" represents the sample where no enzyme has been added and thus the negative control, performed at $25^{\circ} \mathrm{C}$ 

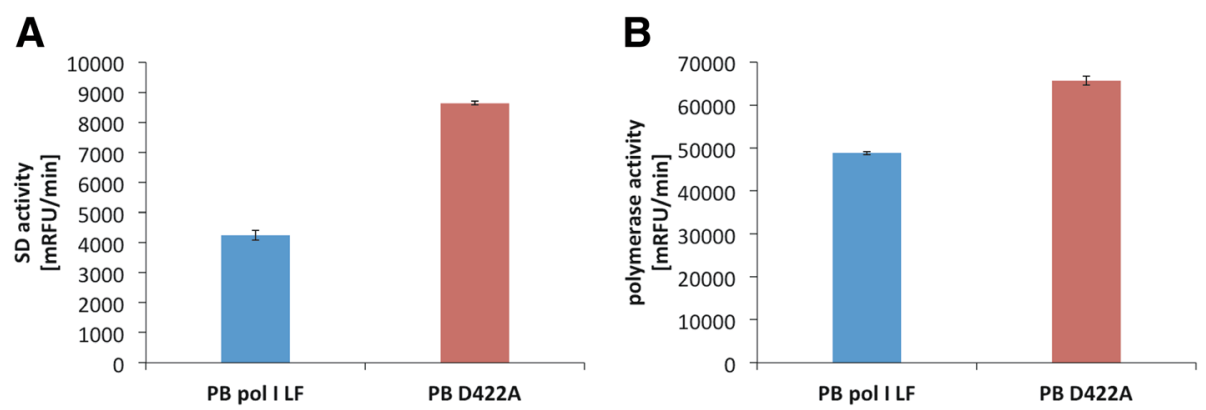

Fig. 4 SD (a) and polymerase (b) activity analysis of polymerase I large fragment from Psychrobacillus sp. (PB pol I LF) and its D422A variant (PB D422A). Activities have been measured using the time-resolved strand-displacement and polymerase activity assay, respectively, at $25^{\circ} \mathrm{C}$ in $50 \mathrm{mM}$ BIS-Tris propane $\mathrm{pH} 8.5,100 \mathrm{mM} \mathrm{NaCl}, 5 \mathrm{mM} \mathrm{MgCl}, 1 \mathrm{mM}$ DTT, $0.2 \mathrm{mg} / \mathrm{ml} \mathrm{BSA}$ and 2\% glycerol. The increase in TAMRA and Fluorescein fluorescence, i.e. SD and polymerase activity, respectively, has been measured as relative fluorescence units over time and is depicted as thousandth (milli) relative fluorescence unit per minute (mRFU/min). For SD $63 \mathrm{ng}$ of each protein and for polymerase activity $36 \mathrm{ng}$ of each protein were used

fingers subdomain of the DNA polymerase I large fragment (Fig. 5, [7]) directed towards the thumb subdomain. According to the right-hand rule one can compare it to a line passing the tip of the index and middle finger. The neighboring secondary structure elements in threedimensional space of O1-helix are the O- and O2-helix, all together forming a 3-helix bundle. Limiting the alignment of PB pol I LF, Gbst pol I LF and Ubts pol I LF to this 3-helix bundle (PB pol I LF aa403-aa446, Fig. 6) revealed high sequence identity among the selected sequences. The aspartate residue at position 422 of $\mathrm{PB}$ pol I LF is conserved in all three polymerases (black triangle in Fig. 6). We changed the respective aspartate residue to an alanine residue in Gbst pol I LF and Ubts pol I LF by site-directed mutagenesis. The respective $\mathrm{D} 422 \mathrm{~A}$ variants of Gbst pol I LF and Ubts pol I LF showed a 2.1 and 2.4 fold increase in SD activity, respectively, when compared to the wild type enzymes (Fig. 7).
The three-dimensional structure of Gbst pol I LF (PDB: 1WXL) shows that the interaction of the side chain of D422 with the side chain of R433 located on O2-helix, is the only direct interaction within the amino-acid sequence covered by the 3-helix bundle. The distance between NH1 of R433 and OD1 of D422 is $2.58 \AA$, indicating a salt bridge. Other than the salt bridge between D422 and R433, interactions within the 3-helix bundle are based on hydrogen bonds between the backbone atoms or hydrophobic interactions (Fig. 8). Substitution of the Asp side chain with a non-anionic side chain would disrupt a possible salt bridge forming with the Arg side chain in the 3-helix bundle motif rendering a more flexible region. Arg433 is conserved in the three polymerases of this study (black circle in Fig. 6), thus the observed increase in strand-displacement activity of the enzymes may be due to a local increase in flexibility.

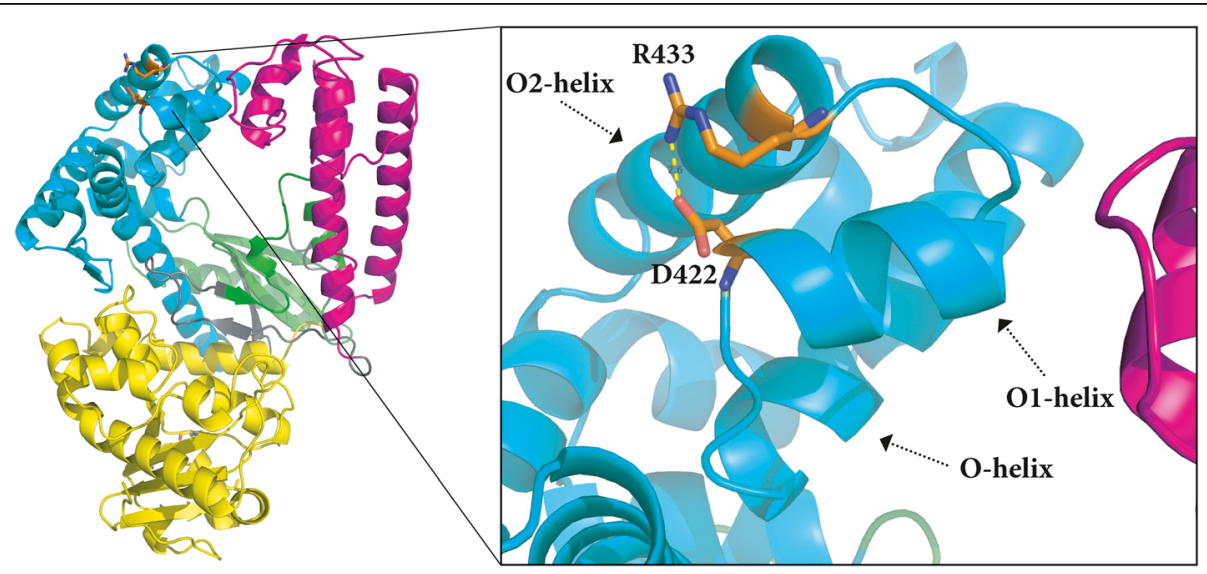

Fig. 5 Cartoon representation of Geobacillus stearothermophilus polymerase I large fragment (PDB code 1XWL). Left showing the subdomains of the DNA polymerase large fragment: fingers (cyan), thumb (magenta) and palm (green). Right showing a close-up view of D422 residue (orange) located on the O1-helix and R433 residue (orange) located on the O2-helix and the distance measurement between them. The cartoon representation has been generated in PyMOL (The PyMol Molecular Graphics System, Version 2.0 Schrödinger, LLC) 


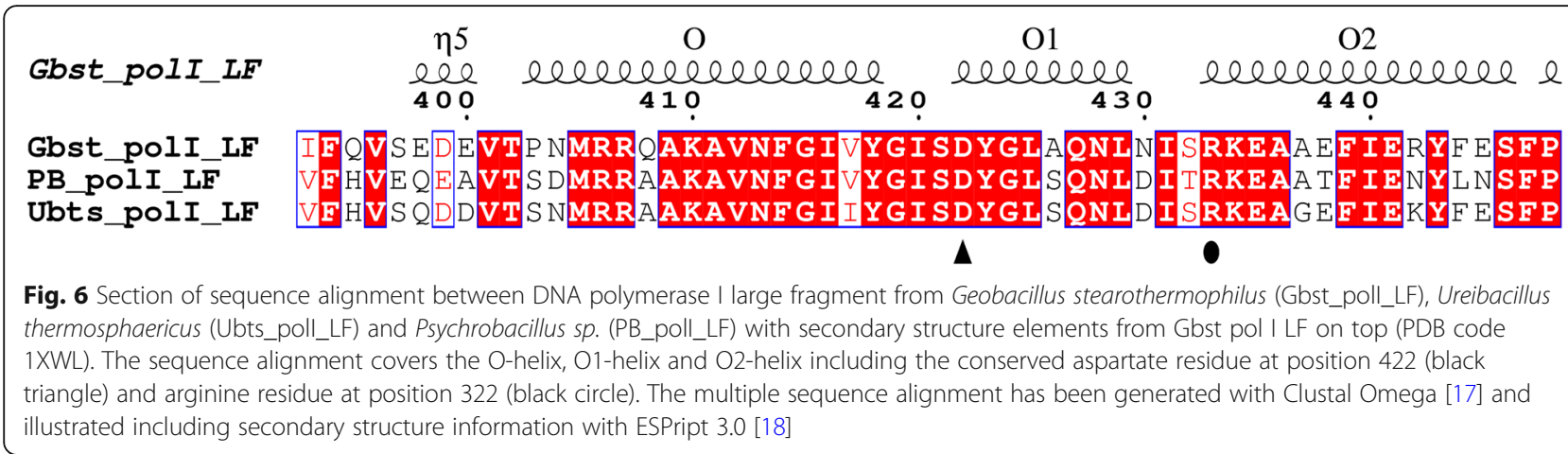

In this study we have shown that changing the negatively charged aspartic acid to alanine at position 422 led to a significant increase in the ability of three A-family DNA polymerase large fragments to perform strand-displacement DNA-synthesis.

\section{Conclusion}

The large fragment of DNA polymerase I from Psychrobacillus $s p$. has efficient polymerase and robust stranddisplacement activity at low-moderate temperature and is thus a well-suited enzyme for DNA synthesis in isothermal amplification technologies at ambient temperatures. The D422A variant identified after molecular evolution of PB pol I LF possessed a 2.5 fold higher SD activity at $25^{\circ} \mathrm{C}$ potentially improving polymerase driven INAAT at ambient temperatures. Our results further show that SD activity of the thermophilic Ubts and Gbst pol I LF could be increased as well by their respective $\mathrm{D} 422 \mathrm{~A}$ variants broadening the benefit of the discovered variant to INAAT methods also at higher temperatures such as LAMP.

\section{Methods}

Cloning of the gene encoding PB polymerase I large fragment

The gene encoding DNA polymerase I from Psychrobacillus sp. (Additional file 4) was cloned into the vector pET151/D-TOPO $^{\circ}$ using the Gateway ${ }^{\circ}$ Technology (Thermo Fisher). The starting material for the polymerase chain reaction was the genomic DNA of Psychrobacillus sp., kindly provided by Marcin M. Pierechod. The bacterium has been collected from marine biota on a cruise of the research vessel Jan Mayen (Norway) around the Lofoten, an archipelago in Northern Norway. The genomic DNA has been isolated using the bead-beating method with the MP Biomedicals ${ }^{\mathrm{mm}}$ FastPrep-24 $4^{\mathrm{mm}}$ Classic Instrument (Thermo Fisher Scientific). By use of the forward and reverse primer (Table 1) the gene has been truncated to the so-called large fragment of the DNA

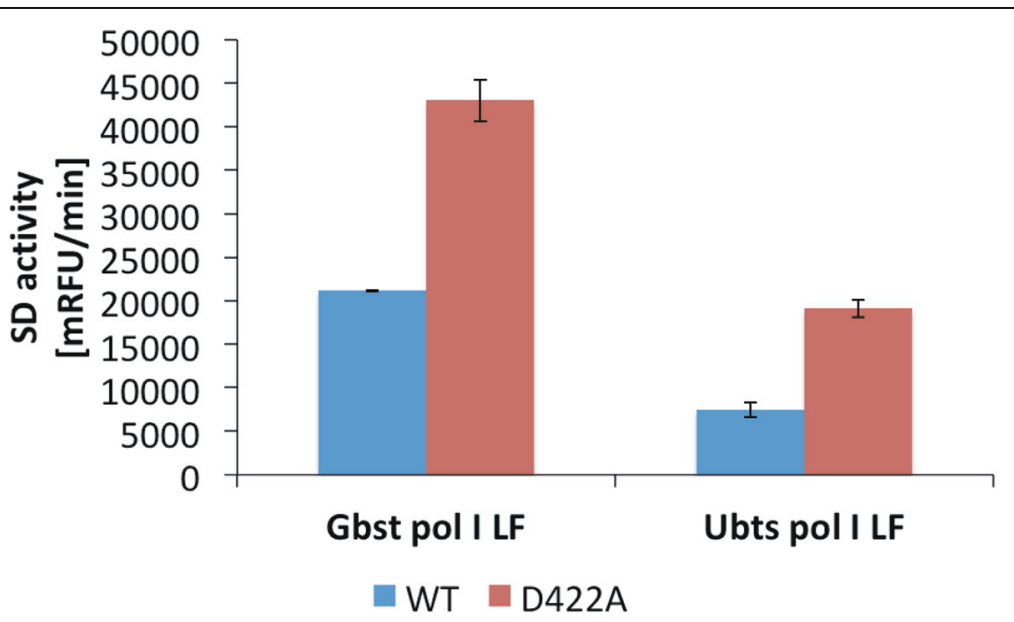

Fig. 7 Strand-displacement activity of polymerase I large fragment from Geobacillus stearothermophilus (Gbst pol I LF) and Ureibacillus thermosphaericus (Ubts pol I LF) (wild type, WT, blue) and their respective D422A variants (red). Time resolved strand-displacement assays were performed at $37^{\circ} \mathrm{C}$ in $20 \mathrm{mM}$ Tris pH 7.9 (at $25^{\circ} \mathrm{C}$ ), $100 \mathrm{mM} \mathrm{KCl}, 10 \mathrm{mM}\left(\mathrm{NH}_{4}\right)_{2} \mathrm{SO}_{4}, 2 \mathrm{mM} \mathrm{MgSO}_{4}, 0.1 \%$ Triton X-100. The increase in TAMRA fluorescence, i.e. enzyme activity, has been measured as relative fluorescence units (RFUs). Fifty nanogram Gbst pol I LF and 100 ng Ubts pol I LF were used in the reaction setup 


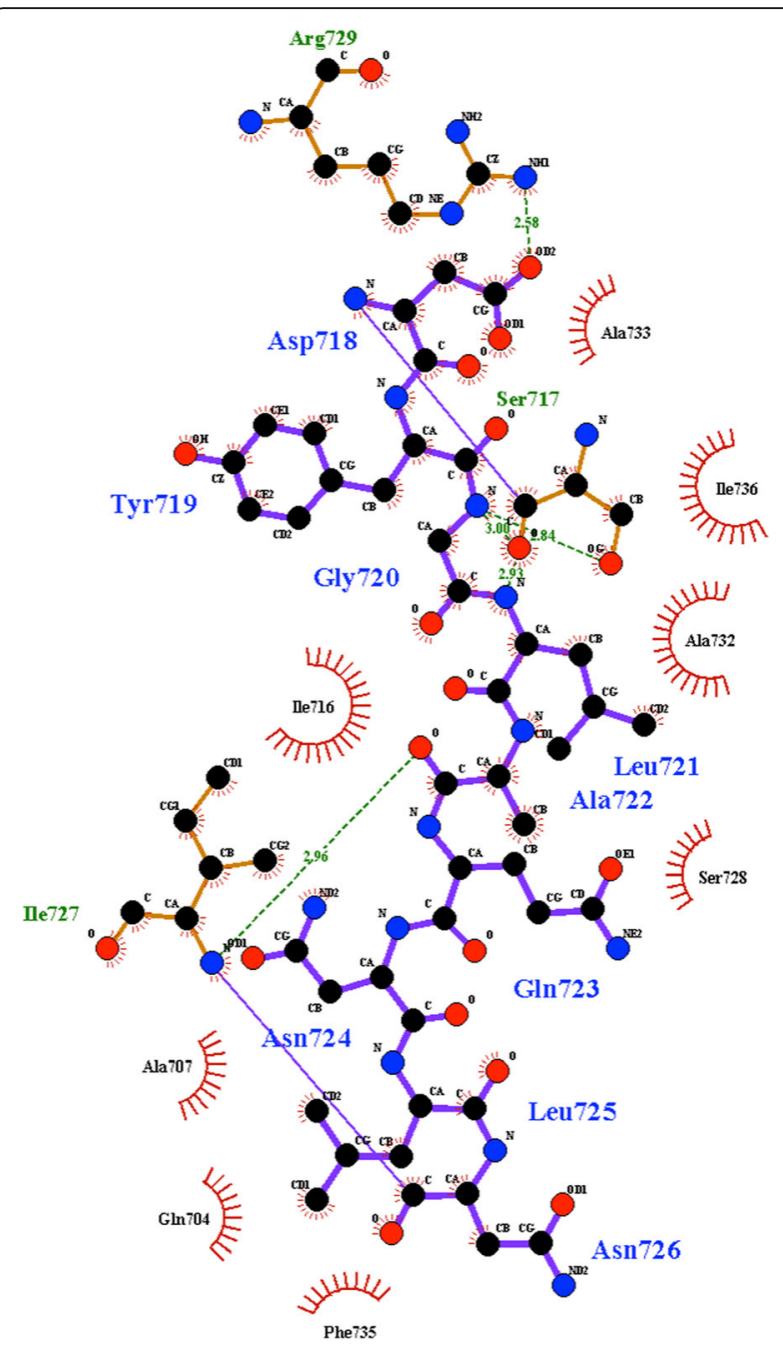

Fig. 8 Schematic diagram generated with LIGPLOT [19] showing the interactions of amino-acid residues residing on O1-helix with neighboring secondary structure elements of Gbst pol I LF (PDB code 1XWL). Asp718 (numbering of the full-length protein of Gbst pol I) corresponds to Asp422 (numbering of PB pol I LF) and Arg729 corresponds to Arg433, respectively. Hydrogen bonds are indicated by dashed lines. Hydrophobic contacts are shown by an arc with spokes radiating towards the ligand atom of contact

polymerase I (Additional file 5), i.e. omitting the $5^{\prime}-3^{\prime}$ exonuclease domain of the protein.

\section{Evolution library creation}

To generate an evolution library of PB pol I LF a fragment thereof covering amino-acid residue 174 to 580, i.e. omitting the first third of the protein, was submitted to codon optimization and molecular evolution experiments (Gene $^{\mathrm{TM}}$ Controlled Randomization technology, Thermo Fisher Scientific) with a default of an average number of 3.5 amino-acid residue mutations per construct in the pET-11a vector. According to the manufacturer the amplified library was digested with NheI/
BamHI and ligated into the pET-11a vector. Ligation reactions were transformed into $E$. coli strain $\mathrm{DH} 5 \mathrm{a}$ and the transformation rate was determined by plating of dilution series. The total number of transformants was $1.53 \times 10^{5} \mathrm{cfu}$. The evolution library was received as glycerol stock preparation, i.e. total cells from the transformation were resuspended in $50 \%$ glycerol at $1.55 \times 10^{10}$ cells $/ \mathrm{ml}$.

\section{Small-scale protein production and semi-purification in 96-well plate format}

The evolution library from Thermo Fisher Scientific was received as glycerol stock preparation. These glycerol stocks consisted of the cloned library in pET-11a vector in DH5 $\alpha$ cells. Plasmid isolation has been performed in 96well format with PureLink ${ }^{\mathrm{TM}}$ Pro Quick96 Plasmid Purification Kit (Thermo Fisher Scientific) from single colonies after striking out the glycerol stock onto LB/Amp plates and overnight cultivation in $1.5 \mathrm{ml}$ Luria Bertani (LB)/ ampicillin $(100 \mu \mathrm{g} / \mathrm{ml})$ thereof. Subsequently the isolated plasmids, each representing a single variant of $\mathrm{PB}$ pol I LF with one or more mutations, have been transformed into in-house produced chemically competent Rosetta 2 (DE3) cells in 48-well format for recombinant protein production. For the overnight culture $1.5 \mathrm{ml} \mathrm{LB/ampicillin}$ $(100 \mu \mathrm{g} / \mathrm{ml})$ were inoculated with $5-6$ colonies of each variant. After incubation overnight at $37^{\circ} \mathrm{C}$ and $220 \mathrm{rpm}$ $250 \mu \mathrm{l}$ were transferred into $3 \mathrm{ml}$ fresh Terrific Broth (TB)/ampicillin $(100 \mu \mathrm{g} / \mathrm{ml})$ media. Cells grew at $37^{\circ} \mathrm{C}$ until $\mathrm{OD}_{600 \mathrm{~nm}}$ reached 0.5-1.0. Gene expression was then induced by addition of $0.1 \mathrm{mM}$ IPTG and carried out at $15^{\circ} \mathrm{C}, 220 \mathrm{rpm}$ for $6-8 \mathrm{~h}$. Cells were harvested by centrifugation with a plate rotor at $500 \mathrm{x} g$ for $10 \mathrm{~min}$. Cell pellets were resuspended in $1 \mathrm{ml} 50 \mathrm{mM}$ HEPES pH7.5 (at $25^{\circ} \mathrm{C}$ ), $500 \mathrm{mM} \mathrm{NaCl}, 10 \mathrm{mM}$ imidazole, 5\% glycerol, 0.25 $\mathrm{mg} / \mathrm{ml}$ lysozyme. Cell disruption was performed by sonication with the VCX 750 from Sonics ${ }^{\circledR}$ (pulse 1.0/1.0, 1 min, amplitude 25\%). Subsequent semi-purification of the proteins was performed in 96-well plate format with His MultiTrap $^{\text {TM }}$ HP (GE Healthcare) according to the instructor's manual. Proteins were eluted in $50 \mu \mathrm{l} 50 \mathrm{mM}$ HEPES pH 7.5 (at $25^{\circ} \mathrm{C}$ ), $500 \mathrm{mM} \mathrm{NaCl}, 500 \mathrm{mM}$ imidazole, $5 \%$ glycerol. Protein concentration was determined with the Bradford assay [20] in 96-well format using $10 \mu \mathrm{l}$ of semipurified protein. During the whole procedure the wild type enzyme has been used as a control.

\section{Cloning of genes encoding polymerase I large fragment from Geobacillus stearothermophilus and Ureibacillus thermosphaericus}

The codon-optimized genes encoding polymerase I large fragment from Geobacillus stearothermophilus (Gbst pol I LF, NCBI protein database: 3TAN_A) and Ureibacillus thermosphaericus (Ubts pol I LF, NCBI protein database: 
Table 1 Forward (forw) and reverse (rev) primer sequences for cloning of wild type enzymes (wt) and for site-directed mutagenesis (substitution of Asp by Ala at position 422, D422A) of DNA polymerase I large fragments

\begin{tabular}{ll}
\hline Primer & Sequence (5' to $3^{\prime}$ direction) \\
\hline Psychrobacillus sp. & \\
PB_wt_forw & CACCACAGAAGTAGCATTCGAGATTGTT \\
PB_wt_rev & TTACTTCGTGTCATACCAAGATGAACC \\
Geoacillus stearothermophilus & \\
Gbst_wt_forw & ACCATCATGGATCCGGCGCCAAAATGGCATTTACCCT \\
Gbst_wt_rev & CATCCGCCAAAACAGCCTTATTTGGCATCATACCAGG \\
Gbst_D422A_forw & GTGTATGGCATCAGCGCTTATGGTCTGGCACAG \\
Gbst_D422A_rev & CTGTGCCAGACCATAAGCGCTGATGCCATACAC \\
Ureibacillus_thermosphaericus & \\
Ureibac_wt_forw & \\
Ureibac_wt_rev & ACCATCATGGATCCGGCGCAGCACTGAGCTTTAAAAT \\
Ureibac_D422A_forw & CATCCGCCAAAACAGCCTTATTTGGCATCGTACCAGG \\
Ureibac_D422A_rev & CTATGGCATCAGCGCTAATGGTCTGAGCC \\
\hline
\end{tabular}

WP_016837139) were purchased from the Invitrogen GeneArt Gene Synthesis service from Thermo Fisher Scientific. The genes were cloned into the vector pTrc99a (encoding an N-terminal $\mathrm{His}_{6}$-tag) by FastCloning after $\mathrm{Li}$ et al. [21]. The corresponding substitution from Asp to Ala at position 422 (PB pol I LF) was introduced using the QuikChange II Site-Directed Mutagenesis Kit (Agilent Technologies) and confirmed by sequencing analysis. Primer sequences for cloning and site-directed mutagenesis are listed in Table 1.

\section{Recombinant protein production and purification PB pol I LF and its D422A variant}

Recombinant protein production of PB pol I LF and its D422A variant was performed in Rosetta 2 (DE3) cells (Novagen $\left.^{\odot}\right)$. Cells grew in TB/ampicillin $(100 \mu \mathrm{g} / \mathrm{ml})$ media and gene expression was induced at $\mathrm{OD}_{600 \mathrm{~nm}}=1.0$ by addition of $0.1 \mathrm{mM}$ IPTG. Protein production was carried out at $15^{\circ} \mathrm{C}, 180 \mathrm{rpm}$ for $6-8 \mathrm{~h}$. For protein purification the pellet of a 1-l cultivation was resuspended in 50 $\mathrm{mM}$ HEPES $\mathrm{pH} 7.5$ (at $25^{\circ} \mathrm{C}$ ), $500 \mathrm{mM} \mathrm{NaCl}, 10 \mathrm{mM}$ imidazole, $5 \%$ glycerol, $0.15 \mathrm{mg} / \mathrm{ml}$ lysozyme, 1 protease inhibitor tablet (cOmplete ${ }^{\mathrm{Tm}}$, Mini, EDTA-free Protease Inhibitor Cocktail, Roche) and incubated on ice for $30 \mathrm{~min}$. If not stated otherwise all steps during the protein purification have been performed either on ice or cooled at $4{ }^{\circ} \mathrm{C}$. Cell disruption was performed by French press (1.37 kbar) and subsequently by sonication with the VCX 750 from Sonics ${ }^{\oplus}$ (pulse 1.0/1.0, $5 \mathrm{~min}$, amplitude $25 \%$ ). In the first step the soluble part of the $\mathrm{His}_{6}$-tagged protein present after centrifugation $\left(48,384 \times \mathrm{g}, 45 \mathrm{~min}, 4^{\circ} \mathrm{C}\right)$ was purified by immobilized $\mathrm{Ni}^{2+}$-affinity chromatography. After a wash step with $50 \mathrm{mM}$ HEPES pH 7.5 (at $25^{\circ} \mathrm{C}$ ), $500 \mathrm{mM} \mathrm{NaCl}, 50 \mathrm{mM}$ imidazole, $5 \%$ glycerol the protein was eluted at an imidazole concentration of $250 \mathrm{mM}$ and further transferred into $50 \mathrm{mM}$ HEPES pH 7.5 (at $25^{\circ} \mathrm{C}$ ), $500 \mathrm{mM} \mathrm{NaCl}, 10 \mathrm{mM} \mathrm{MgCl} 2,5 \%$ glycerol by use of a desalting column. The second step was cleavage of the tag by the TEV protease performed overnight at $4{ }^{\circ} \mathrm{C}$ in 50 $\mathrm{mM}$ Tris pH 8.0 (at $25^{\circ} \mathrm{C}$ ), $0.5 \mathrm{mM}$ EDTA and $1 \mathrm{mM}$ DTT. To separate the protein from the $\mathrm{His}_{6}$-tag and the $\mathrm{His}_{6}$-tagged TEV protease a second $\mathrm{Ni}^{2+}$-affinity chromatography has been performed in the third step in $50 \mathrm{mM}$ HEPES pH 7.5 (at $25^{\circ} \mathrm{C}$ ), $500 \mathrm{mM} \mathrm{NaCl}, 5 \%$ glycerol. The tag-free protein eluted in the flow through after applying the TEV-cleavage reaction onto the column. The $\mathrm{His}_{6}$-tag and the $\mathrm{His}_{6}$-tagged TEV protease have been eluted from the column with $50 \mathrm{mM}$ HEPES pH 7.5 (at $25^{\circ} \mathrm{C}$ ), 500 $\mathrm{mM} \mathrm{NaCl}, 500 \mathrm{mM}$ imidazole, $5 \%$ glycerol. The final protein solution was concentrated and stored with $50 \%$ glycerol at $-20^{\circ} \mathrm{C}$ for activity assays.

\section{Recombinant protein production and purification Gbst and Ubts pol I LF}

Gbst and Ubts pol I LF and their D422A variants have been produced recombinant in Rosetta 2 (DE3) cells (Novagen ${ }^{\odot}$ ). Cultivation of cells has been performed in $\mathrm{LB} /$ ampicillin $(100 \mu \mathrm{g} / \mathrm{ml})$ media and incubation at $37^{\circ} \mathrm{C}$. After induction of gene expression at $\mathrm{OD}_{600 \mathrm{~nm}}=$ 0.5 by addition of $0.5 \mathrm{mM}$ IPTG, protein production was carried out at $37^{\circ} \mathrm{C}$ for $4 \mathrm{~h}$. If not stated otherwise all steps during the subsequent protein purification have been performed either on ice or cooled at $4{ }^{\circ} \mathrm{C}$. The pellet of a $0.5-1$ cultivation was resuspended in $50 \mathrm{mM}$ Tris $\mathrm{pH} 8.0$ (at $25^{\circ} \mathrm{C}$ ), $300 \mathrm{mM} \mathrm{NaCl}, 1 \mathrm{mM}$ EDTA, $1 \mathrm{mM}$ DTT, $10 \mathrm{mM}$ imidazole, $0.15 \mathrm{mg} / \mathrm{ml}$ lysozyme, 1 protease inhibitor tablet (cOmplete $^{\mathrm{Tm}}$, Mini, EDTA-free Protease Inhibitor Cocktail, Roche), incubated on ice for $30 \mathrm{~min}$ 
and then subjected to sonication with the VCX 750 from Sonics $^{\bullet}$ (pulse 1.0/1.0, $15 \mathrm{~min}$, amplitude 25\%) for cell disruption. The soluble part of the $\mathrm{His}_{6}$-tagged protein present after centrifugation $\left(48,384 \mathrm{x} g, 45 \mathrm{~min}, 4{ }^{\circ} \mathrm{C}\right)$ was purified by immobilized $\mathrm{Ni}^{2+}$-affinity chromatography. After a wash step with $50 \mathrm{mM}$ Tris $\mathrm{pH} 8.0$ (at $25^{\circ} \mathrm{C}$ ), $300 \mathrm{mM} \mathrm{NaCl}, 1 \mathrm{mM}$ EDTA, $1 \mathrm{mM}$ DTT, $10 \mathrm{mM}$ imidazole the protein was eluted with gradually increasing the imidazole to $500 \mathrm{mM}$. Fractions containing the protein were collected, and buffer exchange was performed into $20 \mathrm{mM}$ Tris $\mathrm{pH} 7.1$ (at $25^{\circ} \mathrm{C}$ ), $100 \mathrm{mM} \mathrm{KCl}$, $2 \mathrm{mM}$ DTT, $0.2 \mathrm{mM}$ EDTA and $0.2 \%$ Triton X-100 by desalting. After concentration the final protein solution was stored with $50 \%$ glycerol at $-20^{\circ} \mathrm{C}$ for activity assays.

\section{Single-nucleotide incorporation assay}

For determination of optimal temperature for polymerase activity $10 \mu \mathrm{l}$ reactions contained $30 \mathrm{nM}$ substrate, fluorophore-labeled primer annealed to template DNA (Table 2), and $10 \mu \mathrm{M}$ dATP. For PB pol I LF the reaction further contained $5 \mathrm{mM} \mathrm{MgCl}_{2}$ in $50 \mathrm{mM}$ Tris $\mathrm{pH} 8.5,100 \mathrm{mM}$ $\mathrm{NaCl}, 1 \mathrm{mM}$ DTT, $0.2 \mathrm{mg} / \mathrm{ml} \mathrm{BSA}$ and $2 \%$ glycerol. The $\mathrm{pH}$ of the reaction buffer at room temperature was adjusted to $\mathrm{pH} 8.5$ at the respective incubation temperature. The reactions were initiated by addition of protein solution and incubated for $15 \mathrm{~min}$ at various temperatures $\left(0^{\circ} \mathrm{C}-50^{\circ} \mathrm{C}\right)$. As negative control protein dilution buffer (10 mM HEPES pH 7.5 (at $25^{\circ} \mathrm{C}$ ), 1\% glycerol) has been used instead of protein solution.

To examine thermal stability of PB pol I LF $10 \mu$ reactions contained $50 \mathrm{mM}$ BIS-TRIS propane at $\mathrm{pH} 8.5$ (at $25^{\circ} \mathrm{C}$ ), $100 \mathrm{mM} \mathrm{NaCl}, 5 \mathrm{mM} \mathrm{MgCl}, 1 \mathrm{mM}$ DTT, $0.2 \mathrm{mg} /$ $\mathrm{ml} \mathrm{BSA}$ and $2 \%$ glycerol. PB pol I LF was added to the reaction buffer, incubated at various temperatures $\left(0{ }^{\circ} \mathrm{C}\right.$ $-80^{\circ} \mathrm{C}$ ) for $15 \mathrm{~min}$ and afterwards cooled down on ice for $5 \mathrm{~min}$. As negative control protein dilution buffer (10 mM HEPES pH 7.5 (at $25^{\circ} \mathrm{C}$ ), $1 \%$ glycerol) has been used instead of protein solution. The single-nucleotide extension reaction was initiated by addition of $30 \mathrm{nM}$ substrate (Table 2) and $10 \mu \mathrm{M}$ dATP. The mixture was incubated at $25^{\circ} \mathrm{C}$ for $15 \mathrm{~min}$.

Reactions were stopped by addition of $2.5 \mu \mathrm{l}$ denaturing gel loading buffer (95\% formamide, $10 \mathrm{mM}$ EDTA, $0.1 \%$ xylene cyanol) and incubation at $95^{\circ} \mathrm{C}$ for $5 \mathrm{~min}$. For denaturing polyacrylamide gel electrophoresis $(12 \%$ polyacrylamide/7 M urea) a sample volume of $6 \mu \mathrm{l}$ was loaded onto the gel. Gel electrophoresis was performed in $0.5 \mathrm{x}$ TBE buffer (44.5 mM Tris, $44.5 \mathrm{mM}$ boric acid, 1 $\mathrm{mM}$ EDTA) at $50 \mathrm{~W}$ for $1 \mathrm{~h} 15 \mathrm{~min}$ and the gel subsequently scanned for FAM with the PharosFX Plus Imager (Bio-Rad).

Enzyme activity was determined by densitometric measurement of bands representing the extended primer (intensity 1) and the unextended primer (intensity 0 ). Analysis of quantitative data has been performed using standard deviation. The relative conversion rate was calculated as follows:

conversion $[\%]=$ intensity $1 /$ (intensity $0+$ intensity $1)^{*} 100$.

\section{Polymerase activity assay}

The polymerase activity assay is based on a molecular beacon probe (modified from [22]). Fifty microliter reactions consisted of $200 \mathrm{nM}$ substrate, primer annealed to template DNA consisting of fluorophore and quencher (Table 2), and $200 \mu \mathrm{M}$ dNTPs (equimolar amounts of dATP, dGTP, dCTP and dTTP). For PB pol I LF the reaction further contained $5 \mathrm{mM} \mathrm{MgCl} 2$ in $50 \mathrm{mM}$ BIS-

Table 2 Oligonucleotide sequences for enzymatic assay substrates. [FAM]: derivative of the fluorophore Fluorescein, attached to position 5 of the thymidine ring; Dabcyl: N-[4-(4-dimethylamino)phenylazo] benzoic acid, dark quencher (non-fluorescent chromophore) attached to position 5 of the thymidine ring; Flc: Fluorescein, fluorophore attached to position 5 of the thymidine ring; [BHQ2]: Black Hole Quencher 2, dark quencher (non-fluorescent chromophore) - attached to the 5' end via a phosphodiester bond; [TAMRA]: Carboxytetramethylrhodamine, attached to the $3^{\prime}$ end via a phosphodiester linkage

\begin{tabular}{ll}
\hline Oligonucleotide & Sequence (5' to 3' direction) \\
\hline Single-nucleotide incorporation assay & \\
Template & ATTGAGTGGAGATAGTATCGTAGGGTAGTATTGGTGGATA \\
Primer & [FAM] TATCCACCAATACTACCCT \\
Polymerase activity assay & \\
Template & GGCCCGTDabcy'AGGAGGAAAGGACATCTTCTAGCAT \\
Frimer & GCGGGCCGTCAAGTTCATGGCCAGTCAAGTCGTCAGAATTTCGCACCAC \\
Strand-displacement activity assay & \\
Template & \\
Reporter strand & [BHQ2]ATTGAGTGGACAAAGTATCAC \\
"Cold" primer & CGATACTTTGTCCACTCAAT [TAMRA] \\
\hline
\end{tabular}


Tris propane at $\mathrm{pH} 8.5$ (at $25^{\circ} \mathrm{C}$ ), $100 \mathrm{mM} \mathrm{NaCl}, 1 \mathrm{mM}$ DTT, $0.2 \mathrm{mg} / \mathrm{ml}$ BSA and $2 \%$ glycerol. For Gbst and Ubts pol I LF the reaction further contained $20 \mathrm{mM}$ Tris pH 7.9 (at $\left.25^{\circ} \mathrm{C}\right), 100 \mathrm{mM} \mathrm{KCl}, 10 \mathrm{mM}\left(\mathrm{NH}_{4}\right)_{2} \mathrm{SO}_{4}, 2$ $\mathrm{mM} \mathrm{MgSO}_{4}, 0.1 \%$ Triton X-100.

The activity assay was carried out at $25^{\circ} \mathrm{C}$ and $37^{\circ} \mathrm{C}$, respectively, in black 96-well fluorescence assay plates (Corning ${ }^{\circ}$. The reaction was initiated by addition of protein solution. The increase in Fluorescein fluorescence was measured as relative fluorescence units (RFUs) in appropriate time intervals by exciting at 485 $\mathrm{nm}$ and recording emission at $518 \mathrm{~nm}$. Measurements were performed in a SpectraMax ${ }^{\odot}$ Gemini Microplate Reader (Molecular Devices). Analysis of quantitative data has been performed using standard deviation.

\section{Strand-displacement activity assay}

Fifty microliter reactions consisted of $200 \mathrm{nM}$ substrate, "cold" primer and reporter strand annealed to template DNA (Table 2), and $200 \mu \mathrm{M}$ dNTPs (equimolar amounts of dATP, dGTP, dCTP and dTTP). For PB pol I LF and screening of variants from the evolution library the reaction further contained $5 \mathrm{mM} \mathrm{MgCl}_{2}$ in $50 \mathrm{mM}$ BIS-Tris propane at pH $8.5\left(\right.$ at $\left.25^{\circ} \mathrm{C}\right), 100 \mathrm{mM} \mathrm{NaCl}, 1 \mathrm{mM}$ DTT, $0.2 \mathrm{mg} / \mathrm{ml} \mathrm{BSA}$ and $2 \%$ glycerol. For Gbst and Ubts pol I LF the reaction further contained $20 \mathrm{mM}$ Tris pH 7.9 (at $\left.25^{\circ} \mathrm{C}\right), 100 \mathrm{mM} \mathrm{KCl}, 10 \mathrm{mM}\left(\mathrm{NH}_{4}\right)_{2} \mathrm{SO}_{4}, 2 \mathrm{mM} \mathrm{MgSO}_{4}$, $0.1 \%$ Triton $\mathrm{X}-100$.

The activity assay was carried out at $25^{\circ} \mathrm{C}$ and $37^{\circ} \mathrm{C}$, respectively, in black 96-well fluorescence assay plates (Corning $\left.^{\circ}\right)$. The reaction was initiated by addition of protein solution. The increase in TAMRA fluorescence was measured as RFUs in appropriate time intervals by exciting at $525 \mathrm{~nm}$ and recording emission at $598 \mathrm{~nm}$. Measurements were performed in a SpectraMax ${ }^{\circ} \mathrm{M}^{\mathrm{e}}$ Microplate Reader (Molecular Devices). Analysis of quantitative data has been performed using standard deviation.

\section{Mutagenesis, protein production and semi-purification of PB pol I LF 422 variants}

Amino-acid substitutions at position 422 of PB pol I LF have been introduced using the QuikChange II Site-Directed Mutagenesis Kit (Agilent Technologies) and confirmed by sequencing analysis. Starting material for the mutagenesis reaction was the gene encoding PB D422A in the vector pET-11a. Recombinant protein production has been performed in Rosetta 2 (DE3) cells (Novagen ${ }^{\circ}$ ) in 25 $\mathrm{ml} \mathrm{TB} /$ ampicillin $(100 \mu \mathrm{g} / \mathrm{ml})$ media. At $\mathrm{OD}_{600 \mathrm{~nm}}=1.0$ gene expression was induced by addition of $0.1 \mathrm{mM}$ IPTG. Incubation temperature was lowered from $37^{\circ} \mathrm{C}$ to $15^{\circ} \mathrm{C}$ and protein production was carried out at $180 \mathrm{rpm}$ for 6 $8 \mathrm{~h}$. Semi-purification has been performed with PureProteome $^{\text {TM }}$ Nickel Magnetic Beads (Millipore). Cells have been lysed by sonication with VCX 750 from Sonics ${ }^{\circ}$ (pulse 1.0/1.0, $1 \mathrm{~min}$, amplitude 20\%) in $1 \mathrm{ml}$ lysis buffer (50 mM HEPES pH 7.5 (at $25^{\circ} \mathrm{C}$ ), $500 \mathrm{mM} \mathrm{NaCl}, 5 \%$ glycerol, $150 \mu \mathrm{g}$ lysozyme) and processed further according to manufacturer's instructions (washing buffer: $50 \mathrm{mM}$ HEPES pH 7.5 (at $25^{\circ} \mathrm{C}$ ), $500 \mathrm{mM} \mathrm{NaCl}, 5 \%$ glycerol). Final elution of the proteins has been performed with $50 \mu$ elution buffer ( $50 \mathrm{mM}$ HEPES pH 7.5 (at $25^{\circ} \mathrm{C}$ ), 500 $\mathrm{mM} \mathrm{NaCl}, 500 \mathrm{mM}$ imidazole, $5 \%$ glycerol). Protein concentrations have been determined using the Bradford assay [20]. SD activity of PB pol I wild type (Asp) and its variants containing amino-acid substitutions at position 422 has been determined using the time-resolved stranddisplacement activity assay.

\section{Additional files}

Additional file 1: SDS-PAGE analysis of semi-purified PB pol I LF and selected variants. Lane 1: Mark12 ${ }^{\mathrm{TM}}$ Unstained Standard (Thermo Fisher Scientific), lane 2: D442A variant, lane 3: variant 2, lane 4: variant 3, lane 5: PB pol I LF. PB pol I LF and its variants have been purified from a 500-ml cultivation pellet by immobilized $\mathrm{Ni}^{2+}$-affinity chromatography including cleavage of the $\mathrm{His}_{6}$-tag by TEV protease. For each sample $11 \mu \mathrm{g}$ of semipurified protein have been loaded onto the gel. (TIF $3875 \mathrm{~kb}$ )

Additional file 2: Sequencing analysis after directed evolution of PB pol I LF. The diagram was generated with SnapGene ${ }^{\circledast}$ software (from GSL Biotech) and shows the triplet coding for alanine (GCT, blue background) after base exchange by random mutagenesis of the wild type sequence coding for an aspartate (GAT) at the respective position. (DOC $461 \mathrm{~kb}$ )

Additional file 3: The effect of amino-acid substitution at position 422 of PB pol I LF (Asp) on SD activity. Activity has been measured (in duplicates) using the time-resolved strand-displacement activity assay at $25^{\circ} \mathrm{C}$ in $50 \mathrm{mM}$ BIS-Tris propane $\mathrm{pH} 8.5,100 \mathrm{mM} \mathrm{NaCl}, 5 \mathrm{mM} \mathrm{MgCl} 2,1 \mathrm{mM}$ DTT, $0.2 \mathrm{mg} / \mathrm{ml}$ BSA and $2 \%$ glycerol. The increase in TAMRA fluorescence has been measured as relative fluorescence units over time and is depicted as specific SD activity as thousandth (milli) relative fluorescence unit per minute per $\mu \mathrm{g}$ protein (mRFU/min/ $\mu \mathrm{g}$ ). (DOCX $56 \mathrm{~kb}$ )

Additional file 4: Nucleotide sequence encoding PB pol I LF. (DOC $25 \mathrm{~kb}$ )

Additional file 5: Amino-acid sequence of PB pol I LF. (DOCX 43 kb)

\section{Abbreviations}

BSA: bovine serum albumin; dNTPs: deoxynucleotide triphosphates; DTT: Dithiothreitol; EDTA: ethylenediaminetetraacetic acid; IPTG: Isopropyl $\beta$ -

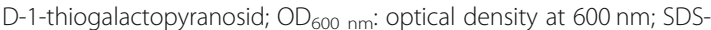
PAGE: Sodium dodecyl sulfate polyacrylamide gel electrophoresis

\section{Acknowledgements \\ We thank Marcin M. Pierechod for providing the genomic DNA of Psychrobacillus sp. and Adele K. Williamson for critical reading of the manuscript.}

\section{Author's contribution}

ANL and YP designed the experiments and analyzed the generated data. YP and MKG performed the experiments. ANL and YP contributed equally to the manuscript. All authors read and approved the final manuscript.

\section{Funding}

This project was funded by BIOTEK2021 programme of the Research Council of Norway (NRC), under grant No. 226193. The authors, therefore, acknowledge with thanks NRC for financial support. 


\section{Availability of data and materials}

All data generated or analyzed during this study are included in this published article or available from the corresponding author on reasonable request.

\section{Ethics approval and consent to participate}

Not applicable.

\section{Consent for publication}

Not applicable.

\section{Competing interests}

Yvonne Piotrowski and Atle Noralf Larsen are the authors of Patent Publication No. WO/2017/162765 and International Patent Application No. PCT/EP2018/085342. Both patents are licensed to ArcticZymes AS. Man Kumari Gurung has no competing interests.

Received: 16 May 2019 Accepted: 2 August 2019

Published online: 09 August 2019

\section{References}

1. Burgers PM, Koonin EV, Bruford E, Blanco L, Burtis KC, Christman MF, Copeland WC, Friedberg EC, Hanaoka F, Hinkle DC, Lawrence CW, Nakanishi M, Ohmori H, Prakash L, Prakash S, Reynaud CA, Sugino A, Todo T, Wang Z, Weill JC, Woodgate R. Eukaryotic DNA polymerases: proposal for a revised nomenclature. J Biol Chem. 2001;276(47):43487-90.

2. Patel PH, Suzuki M, Adman E, Shinkai A, Loeb LA. Prokaryotic DNA polymerase I: evolution, structure, and "base flipping" mechanism for nucleotide selection. J Mol Biol. 2001;308(5):823-37.

3. Hamilton SC, Farchaus JW, Davis MC. DNA polymerases as engines for biotechnology. Biotechniques. 2001;31(2):370 -376, 378-380, 382-373.

4. Reha-Krantz LJ. Recent patents of gene sequences relative to DNA polymerases. Recent Pat DNA Gene Seq. 2008;2(3):145-63.

5. Saiki RK, Gelfand DH, Stoffel S, Scharf SJ, Higuchi R, Horn GT, Mullis KB, Erlich HA. Primer-directed enzymatic amplification of DNA with a thermostable DNA polymerase. Science. 1988:239(4839):487-91.

6. Jacobsen $\mathrm{H}$, Klenow $\mathrm{H}$, Overgaard-Hansen $\mathrm{K}$. The $\mathrm{N}$-terminal amino-acid sequences of DNA polymerase I from Escherichia coli and of the large and the small fragments obtained by a limited proteolysis. Eur J Biochem. 1974; 45(2):623-7.

7. Kiefer JR, Mao C, Hansen CJ, Basehore SL, Hogrefe HH, Braman JC, Beese LS. Crystal structure of a thermostable Bacillus DNA polymerase I large fragment at 2.1 a resolution. Structure. 1997:5(1):95-108.

8. Kaushik N, Pandey VN, Modak MJ. Significance of the O-helix residues of Escherichia coli DNA polymerase I in DNA synthesis: dynamics of the dNTP binding pocket. Biochemistry. 1996;35(22):7256-66.

9. Singh K, Srivastava A, Patel SS, Modak MJ. Participation of the fingers subdomain of Escherichia coli DNA polymerase I in the strand displacement synthesis of DNA. J Biol Chem. 2007;282(14):10594-604.

10. Notomi T, Okayama H, Masubuchi H, Yonekawa T, Watanabe K, Amino N, Hase T. Loop-mediated isothermal amplification of DNA. Nucleic Acids Res. 2000;28(12):E63

11. Caliendo AM, Gilbert DN, Ginocchio CC, Hanson KE, May L, Quinn TC, Tenover FC, Alland D, Blaschke AJ, Bonomo RA, Carroll KC, Ferraro MJ, Hirschhorn LR, Joseph WP, Karchmer T, Maclntyre AT, Reller LB, Jackson AF. Infectious diseases Society of a. better tests, better care: improved diagnostics for infectious diseases. Clin Infect Dis. 2013:57(Suppl 3):S139-70.

12. Kettler $\mathrm{H}$, White K, Hawkes S. Mapping the landscape of diagnostics for sexually transmitted infections. Geneva: World Health Organization; 2004. p. 1-36.

13. de Paz HD, Brotons P, Munoz-Almagro C. Molecular isothermal techniques for combating infectious diseases: towards low-cost point-of-care diagnostics. Expert Rev Mol Diagn. 2014;14(7):827-43.

14. Craw P, Balachandran W. Isothermal nucleic acid amplification technologies for point-of-care diagnostics: a critical review. Lab Chip. 2012;12(14):2469-86.

15. Gill P, Ghaemi A. Nucleic acid isothermal amplification technologies: a review. Nucleosides Nucleotides Nucleic Acids. 2008;27(3):224-43.

16. Altschul SF, Gish W, Miller W, Myers EW, Lipman DJ. Basic local alignment search tool. J Mol Biol. 1990;215(3):403-10.
17. Sievers F, Wilm A, Dineen D, Gibson TJ, Karplus K, Li W, Lopez R, McWilliam $\mathrm{H}$, Remmert M, Soding J, Thompson JD, Higgins DG. Fast, scalable generation of high-quality protein multiple sequence alignments using Clustal omega. Mol Syst Biol. 2011;7:539.

18. Robert X, Gouet P. Deciphering key features in protein structures with the new ENDscript server. Nucleic Acids Res. 2014;42(Web Server issue:W320-4.

19. Wallace AC, Laskowski RA, Thornton JM. LIGPLOT: a program to generate schematic diagrams of protein-ligand interactions. Protein Eng. 1995:8(2):127-34

20. Bradford MM. A rapid and sensitive method for the quantitation of microgram quantities of protein utilizing the principle of protein-dye binding. Anal Biochem. 1976;72:248-54.

21. Li C, Wen A, Shen B, Lu J, Huang Y, Chang Y. FastCloning: a highly simplified, purification-free, sequence- and ligation-independent PCR cloning method. BMC Biotechnol. 2011;11:92.

22. Summerer $D$, Marx A. A molecular beacon for quantitative monitoring of the DNA polymerase reaction in real-time. Angew Chem Int Ed Engl. 2002; 41(19):3620-3622, 3516.

\section{Publisher's Note}

Springer Nature remains neutral with regard to jurisdictional claims in published maps and institutional affiliations.
Ready to submit your research? Choose BMC and benefit from:

- fast, convenient online submission

- thorough peer review by experienced researchers in your field

- rapid publication on acceptance

- support for research data, including large and complex data types

- gold Open Access which fosters wider collaboration and increased citations

- maximum visibility for your research: over $100 \mathrm{M}$ website views per year

At BMC, research is always in progress.

Learn more biomedcentral.com/submissions 